\title{
Assessment of the General Goals of Civil Service Reforms in the Gambia and Its Implementations
}

\author{
Momodou Lamin Tarro \\ School of Business and Public Administration, University of the Gambia (UTG)
}

\begin{abstract}
This study examined the strategic goals of civil service reforms in The Gambia and its implementation in the Gambian civil service. This was aimed to identify challenges facing the implementations and policy options towards assisting the process. This study adopted primary data collection through the administration of questionnaires and interview guide. The population of the study comprises the senior and middle level staff of Public Service Commission (PSC), Personnel Management Office (PMO), Ministry of Health (MoH) and Ministry of Basic and Secondary Education (MoBSE) which were purposively selected. In all, there are 189 senior and middle management staff in the four Ministries/Departments/ Agencies (MDAs) which breakdown goes thus: PMO (37), PSC (6), MoBSE (87) and MoH (59). Questionnaire was administered on the staff of the four MDAs while interview was conducted with the Permanent Secretaries, Deputy Permanent Secretaries and a former Secretary General and Head of Civil Service. Out of the 189 copies of questionnaire administered, 140 were retrieved. The data collected were analyzed using descriptive statistical methods such as frequency distribution and percentages. The results of the study revealed that majority of the respondents identified reinforcement of meritocracy, due process and professionalism, enhancement of administrative culture, improvement of efficiency and quality service delivery, institutionalization of a system that engenders separation between politics and administration as goals and objectives of civil service reforms in The Gambia. The research has also shown that the Civil service sometimes adhere to meritocratic principles, gives attention to diversity in terms of ethnic groups, , provide detailed policies and standard procedures, conduct induction programmes, made available the General Orders and code of ethics to employees, conducts performance assessment, recruitment and selection are encouraging, recruitment and promotion processes are reviewed at regular intervals and training programmes are based on outcome of need assessment. Despite its performance, the four MDAs also continues to face challenges in terms of human and material resources as alluded to by the responses of numerous respondents during the study. The performance of the institution was said to have been hindered by low commitment from government, lack of capacity at PMO, proliferation of public institutions, poor ethics management, lack of clarity of institutional roles, lack of appraisal system, unclear policies, lack of job fit and organization fit, among others. The main thesis of this study is that reforms of The Gambia civil service did enhance personnel administration systems and practices of the civil service institutions of The Gambia but only to a large extent.
\end{abstract}

Keywords: Civil Service, Reforms, Personnel, Recruitment, The Gambia.

DOI: $10.7176 /$ PPAR/11-7-02

Publication date:August $31^{\text {st }} 2021$

\section{Introduction}

A lot has been written on reforms in both developing and developed countries which are directed towards liberalizing the public space. In a study by Mano and Milton (2020), identified good governance as a recipe for public service broadcasting reforms. They further noted that an active, proactive and coalition of civil society in Southern Africa will help the ongoing reforms in those countries. This notion is a derivation of the existing deficiency in most post-colonial states in African states which has made institutions in these states to be inefficient and wasteful in the course of management.

This has been compounded due to many years of authoritarian system and devoid of democratic values that expected to ushered in meritocracy and system of good governance. This aforementioned deduction described the Republic of The Gambia after many years of her independence whereby public institutions were used as private property of certain ruling elites. This situation has made European countries to be sympathetic in terms of Foreign Aid and other technical help in assisting the country (The World Bank, 2020). However, in another study by Ukwandu and Ijere (2020), argued that the failure of reforms in post-colonial state which Gambia is inclusive occurred as a result of weak system that did not embraced radical and comprehensive model to captured the needed changes in the governmental institutions. The Gambian case has revolved around series of methods of reforms but yet the adopted reforms have not translated into meaningful results in the country. It is on this backdrop this study seeks to interrogate Civil Service Reforms, Personnel Administration Systems and Practices in the Civil Service Institutions of The Gambia. The few studies and policies made towards arresting public service inefficiency in past administrations have not given the desired results in the country and which has intensified influx of foreign aids into Gambia (Ceesay, 2006; The World Bank, 2020). Hence, this study seeks to 
fill the gap through the assessment of Gambian civil service reforms, personnel administration system and its practices in the ongoing political dispensation. The most information presented in this study is derived from the $\mathrm{PhD}$ work of ML Tarro on civil service reforms in the Gambia (Tarro, 2020). The arrangement of this study begins with the introduction, followed by theories, methodology, presentation of data and data analysis; and concluding remarks.

\section{The Systems Theory}

David Easton is one of the leading social scientists of the system theory and whose ideas is predicated on the workings of a political system in terms of analyzing policy making and its related component decisionmaking. For him public policy as a political system's response to demands arising from its environment in the form of problems that call for solution (Easton, 1957). The system comprises of those identifiable and interrelated institutions and activities-usually thought of as governmental institutions and political process that generally involve the public administrative system in the making of authoritative allocation of values (decisions). According to this model, the organization as a system is composed of interconnected and mutually dependent sub-systems. The system model facilitates different components of the organization to operate in an organized and correlated manner. The interaction between the different components of the organization is dependent upon the linking processes, which consist of communication, balance and decision making. The structure of open system model stresses the complexity and variability of the individual parts of the organization such as individual participants and subgroups and the looseness of connection among them.

Each parts of the organization work as semi-autonomous parts and capable of semi- autonomous action. Each part is loosely linked to other parts and individuals and subgroups form and leave coalitions therefore, the coordination and control become problematic (Kast and Rosenweig, 1988). The open systems theory is among the most influential conceptual paradigms for understanding the delivery of services in organisations.

Hood (1991) defines a system as a collection of interdependent parts which form some whole. According to him, the major characteristics of an open system are:

i. They receive inputs from the environment;

ii. They convert these inputs to outputs; and

iii. They discharge their outputs into their environment.

Katz and Kahn (2009) identified several subsystems of an organization like:

i. Production or technical subsystem - concerned with the accomplishment of basic tasks of the organization; ii. Supportive subsystem which procure the inputs and dispose the outputs of the production subsystem;

iii. Maintenance subsystems - concerned with the stability and predictability of the organization;

iv. Adaptive subsystems - concerned with what the organization might become: they deal with issues of change in the environment; and

v. Managerial subsystems - these deal with managerial functions of planning, coordination and control of the total system (Dzimbiri, 2009).

Katz and Kahn (2009) maintain that an organization be looked at as an open system which continuously interact and depends on its environment. The open system theory emphasizes on openness, interaction, exchange of inputs and outputs between organizations and their environments. Organizations are not closed systems, but are open to and depend on flow of personnel, other resources and information from outside into it. The link between the study and the theory is about creating public institutions that are open to change, institutions that are ready to embrace change so that those obstacles that continuously deter reform efforts might be removed thereby improving delivery of services which is the core business of reform.

\section{Figure-2.1. Framework of the System Theory \\ Open Systems Theory}

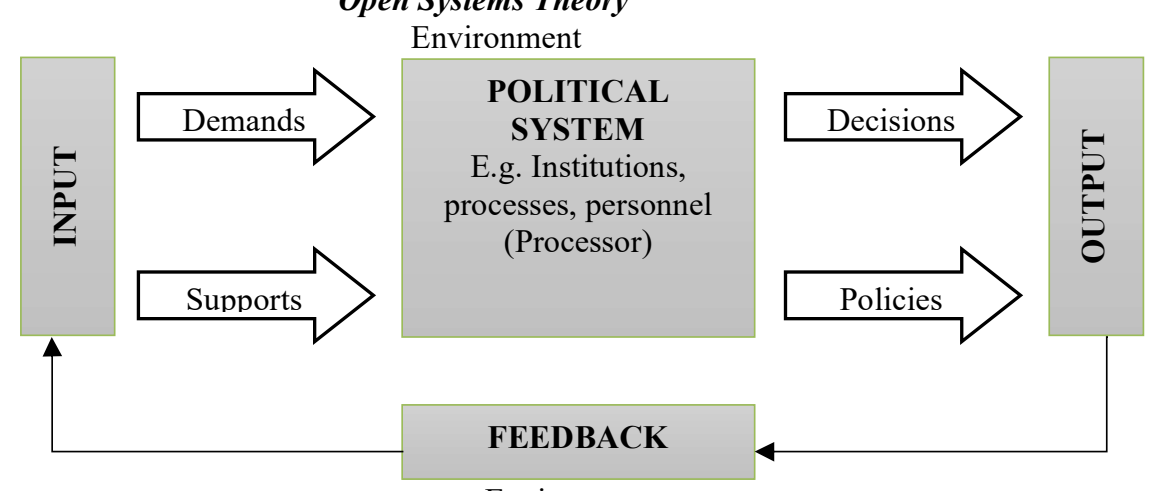

Environment

Source: (Easton, 1957) 
The above model views public policy as a political system's response to demands arising from its environment in the form of problems that call for solution.

The system comprises of those identifiable and interrelated institutions and activities-usually thought of as governmental institutions and political process that generally involve the public administrative system in the making of authoritative allocation of values (decisions).

The environment consists of all phenomena- the social system, the economic system, the biological settingthat is external to the boundaries of the political system. Thus analytically one can separate the political system from all the other components of a society.

The input into the system comes from the environment in the form of demands (claims for action) and support (payment of taxes etc) for the solution of problems. The input could be triggered by an aggrieved person or groups. The input is converted through the political system reviewing alternatives that would be presented to the policy-makers largely by or channeled through the public administrators as part of technical inputs, writing of memoranda to support a particular bill (proposal), putting together the technical as well as financial documents, preparation of the document to meet specific formats among others. The input and the resultant choice are also based on the cost benefit analysis of all inputs from the public administrator in their technical roles.

The input is converted and released as outputs. These include laws, rules, judicial decisions, policies and programmes. It is what emerges out of the system that is generally regarded as the "authoritative allocation of values". When policy is further defined as "intent", reference is then being made to the fact that the policy document is only a hypothesis of what would happen if the framework is implemented and managed which is largely undertaken by the public administrative system.

The linkage in terms of feedback indicates or provides the critical analysis of the performance of public policy and the reaction of the citizens as clients for policy makers to know how well or not they have succeeded in solving the problems that have come from the environment as a demand. This may result in the amendment of the policy either in full when it is abrogated or in part when some specific changes are recommended thereby repeating the policy making cycle.

The theory underpinning the study is the open system theory of Katz and Kahn. It is worth noting that the concept of reform is viewed as a process towards achieving a desired end. For this reason, this study is informed by the open system theory which concerns itself with conceptualizing ways to improve the administrative techniques needed to realize the policy goals of government. The policy goals of the governments of African countries is to improve service delivery. The open system theory is thus consistent with the fact that "many developing countries have put in place the reforms to handle and achieve this important goal of meeting its citizen's needs" (Mokhothu, 2006).

\section{Population of the Study}

The population of the study consisted of the middle and senior management officers who work in the selected four institutions. Based on the information gathered during a pre-field visit, the population of the study is 189 and the pattern ministry by ministry looks as presented on table 3.1 below.

Table 3.1: Table Showing Population Distribution of Respondents

\begin{tabular}{|l|l|l|l|c|}
\hline S/N & Name of Institution & $\begin{array}{l}\text { Senior Management } \\
\text { Staff }\end{array}$ & $\begin{array}{l}\text { Middle Management } \\
\text { Staff }\end{array}$ & Total \\
\hline 1. & Personnel Management Office (PMO) & 19 & 18 & 37 \\
\hline 2. & $\begin{array}{l}\text { Ministry of Basic and Secondary Education } \\
\text { MoBSE) }\end{array}$ & 30 & 57 & 87 \\
\hline 3. & Ministry of Health & 25 & 34 & 59 \\
\hline 4 & Public Service Commission & 06 & ---- & 06 \\
\hline & Total & 80 & 109 & 189 \\
\hline
\end{tabular}

Source: (Tarro, 2020)

\section{Sampling Technique and Sample Size}

The population of the study is the entire work force of The Gambia Civil Service which is made up of 18 Ministries. The target respondents are senior and middle management of the four (4) selected government departments/ministries. These are; the Personnel Management Office (PMO), Public Service Commission (PSC), Ministry of Basic and Secondary Education (MoBSE), and Ministry of Health (MoH). The PMO and PSC were purposively selected because the former is saddled with the responsibility of coordinating the MDAs including the administrative reform programmes and the latter sees to the recruitment and regulation of the conduct of the workforce making the two relevant when considering personnel administration in the Civil Service. The MoBSE and $\mathrm{MoH}$ were selected based on convenience sampling method. In all, there are 189 senior and middle management staff in the four (4) ministries and departments which breakdown goes thus: PMO (37), PSC (6), 
MoBSE (87), and MoH (59).

Due to the size of the population, $100 \%$ of it were sampled as presented in table 3.2 below. The population excludes the Principal Officers such as the Minister and Permanent Secretaries who are sampled for interview.

Table 3.2: Table showing study population and sample size

\begin{tabular}{|l|l|l|}
\hline INSTITUTIONS & Population of study & Sample Size \\
\hline PSC & 6 & 6 \\
\hline MOBSE & 87 & 87 \\
\hline MOH & 59 & 59 \\
\hline PMO & 37 & 37 \\
\hline Total & $\mathbf{1 8 9}$ & $\mathbf{1 8 9}$ \\
\hline
\end{tabular}

Source: (Tarro, 2020).

Table showing questionnaire administration and retrieval rate

\begin{tabular}{|l|l|l|l|}
\hline INSTITUTIONS & $\begin{array}{l}\text { Number of Questionnaire } \\
\text { Administered }\end{array}$ & $\begin{array}{l}\text { Number of Questionnaire } \\
\text { retrieved }\end{array}$ & $\begin{array}{l}\text { Percentage } \\
\text { retrieval }\end{array}$ \\
\hline PSC & 6 & 4 & 66.7 \\
\hline MOBSE & 87 & 68 & 78.1 \\
\hline MOH & 59 & 50 & 84.7 \\
\hline PMO & 37 & 18 & 48.6 \\
\hline Total & $\mathbf{1 8 9}$ & $\mathbf{1 4 0}$ & $\mathbf{7 4 . 1 \%}$ \\
\hline
\end{tabular}

Source: (Tarro, 2020).

\section{Method of Data Analysis}

Data analysis was carried out using descriptive statistical methods. This include the use of simple percentages, frequency distribution as well as graphical representations for illustration. The analysis was done with the assistance of version 22 of the Statistical Package for Social Sciences (SPSS).

\section{Respondents' Views on the Goals and Objectives of Civil Service Reforms.}

As revealed in table 4.2.1a, the study has aligned with the basic goals of reforms which has been documented in extant literature (Ring, Ervik, \& Linden, 2020; Adejuwon, 2018). For Farazmand (1999), argued that the primary goal of reforms is to cause institutional changes with the view of meeting up with developmental objectives. This can be made possible through the mechanism of merit system; promotion of ethical standard, culture of discipline and digitization of the system as identified in the policy framework as it is done in most Asian countries (Sen, Nepal, \& Jamasb, 2018; Ring et al.,2020). This idea has been subscribed to by most respondents as revealed in the table 4.2.1a below and conversely in realities in most developing states is the problem of weak and complex system which has been a huge barrier in having a robust reforms system (Ukwandu \& Ijere, 2020).

Table 1: Respondents' views on Goals and Objectives of Civil Service Reforms in The Gambia Likert Scale: Strongly Agree (SA); Agree (A); Undecided (U); Disagree (D); Strongly Disagree (SD)

\begin{tabular}{|c|c|c|c|c|c|c|c|}
\hline Goals and Objectives & SA & $\mathbf{A}$ & $\mathbf{U}$ & D & SD & Total & Mean \\
\hline $\begin{array}{l}\text { To reinforce meritocracy, due process } \\
\text { and professionalism in the decisions of } \\
\text { personnel administration (appointment, } \\
\text { discipline, promotion etc) through clear } \\
\text { policies, structures, systems, standards } \\
\text { and procedures }\end{array}$ & $\begin{array}{c}96 \\
(68.57) \\
\end{array}$ & $\begin{array}{c}41 \\
(29.29) \\
\end{array}$ & $\begin{array}{c}1 \\
(0.71)\end{array}$ & $\begin{array}{c}2 \\
(1.43)\end{array}$ & $\begin{array}{c}0 \\
(0)\end{array}$ & $\begin{array}{c}140 \\
(100)\end{array}$ & 4.65 \\
\hline $\begin{array}{l}\text { Enhance administrative culture that } \\
\text { guarantees discipline, performance, and } \\
\text { good ethical conduct }\end{array}$ & $\begin{array}{c}92 \\
(65.71) \\
\end{array}$ & $\begin{array}{c}41 \\
(29.9) \\
\end{array}$ & $\begin{array}{c}5 \\
(3.57) \\
\end{array}$ & $\begin{array}{c}2 \\
(1.43) \\
\end{array}$ & $0(0)$ & $\begin{array}{c}140 \\
(100) \\
\end{array}$ & 4.59 \\
\hline $\begin{array}{l}\text { Optimal organization and staffing of the } \\
\text { civil service that align the overall } \\
\text { structure of government for efficiency } \\
\text { and effectiveness }\end{array}$ & $\begin{array}{c}73 \\
(52.14) \\
\end{array}$ & $\begin{array}{c}54 \\
(38.57)\end{array}$ & $\begin{array}{c}11 \\
(7.86)\end{array}$ & $\begin{array}{c}1 \\
(0.71)\end{array}$ & $\begin{array}{c}1 \\
(0.71)\end{array}$ & $\begin{array}{c}140 \\
(100)\end{array}$ & 4.41 \\
\hline $\begin{array}{l}\text { Improved face of service delivery by } \\
\text { fostering new attitudes such as increased } \\
\text { commitment to citizen consultation, } \\
\text { courtesy and dedication }\end{array}$ & $\begin{array}{c}71 \\
(50.71)\end{array}$ & $\begin{array}{c}53 \\
(37.86)\end{array}$ & $\begin{array}{c}10 \\
(7.14)\end{array}$ & $\begin{array}{c}6 \\
(4.29)\end{array}$ & $\begin{array}{c}0 \\
(0)\end{array}$ & $\begin{array}{r}140 \\
(100)\end{array}$ & 4.35 \\
\hline
\end{tabular}




\begin{tabular}{|c|c|c|c|c|c|c|c|}
\hline $\begin{array}{l}\text { To attract, retain and motivate optimal } \\
\text { number of qualified technical and } \\
\text { professional personnel through more } \\
\text { equitable, adequate and fair } \\
\text { remuneration. }\end{array}$ & $\begin{array}{c}99 \\
(70.71) \\
\end{array}$ & $\begin{array}{c}34 \\
(24.29) \\
\end{array}$ & $\begin{array}{c}2 \\
(1.43) \\
\end{array}$ & $\begin{array}{c}5 \\
(3.57) \\
\end{array}$ & $\begin{array}{c}0 \\
(0) \\
\end{array}$ & $\begin{array}{c}140 \\
(100) \\
\end{array}$ & 4.62 \\
\hline $\begin{array}{l}\text { Enhance transparency and accountability } \\
\text { in government }\end{array}$ & $\begin{array}{c}98 \\
(70.00)\end{array}$ & $\begin{array}{c}31 \\
(22.14)\end{array}$ & $\begin{array}{c}4 \\
(2.86)\end{array}$ & $\begin{array}{c}5 \\
(3.57)\end{array}$ & $\begin{array}{c}2 \\
(1.43)\end{array}$ & $\begin{array}{c}140 \\
(100)\end{array}$ & 4.56 \\
\hline $\begin{array}{l}\text { Improved efficiency and cost } \\
\text { effectiveness in Public Institutions } \\
\text { (ensuring that cost of administration are } \\
\text { proportionate to results }\end{array}$ & $\begin{array}{c}72 \\
(51.43) \\
\end{array}$ & $\begin{array}{c}56 \\
(40.00) \\
\end{array}$ & $\begin{array}{c}6 \\
(4.29) \\
\end{array}$ & $\begin{array}{c}4 \\
(2.86) \\
\end{array}$ & $\begin{array}{c}2 \\
(1.43) \\
\end{array}$ & $\begin{array}{c}140 \\
(100)\end{array}$ & 4.37 \\
\hline $\begin{array}{l}\text { To improve the image of the public } \\
\text { (perceived as outdated and not citizen } \\
\text { friendly, inefficient and ineffective) }\end{array}$ & $\begin{array}{c}53 \\
(37.86) \\
\end{array}$ & $\begin{array}{c}47 \\
(33.57) \\
\end{array}$ & $\begin{array}{c}26 \\
(18.57) \\
\end{array}$ & $\begin{array}{c}8 \\
(5.71) \\
\end{array}$ & $\begin{array}{c}6 \\
(4.29) \\
\end{array}$ & $\begin{array}{c}140 \\
(100)\end{array}$ & 3.95 \\
\hline $\begin{array}{l}\text { Institutionalize a system that engenders } \\
\text { separation between politics and } \\
\text { administration (political neutrality) }\end{array}$ & $\begin{array}{c}81 \\
(57.86) \\
\end{array}$ & $\begin{array}{c}42 \\
(30.00) \\
\end{array}$ & $\begin{array}{c}7 \\
(5.00) \\
\end{array}$ & $\begin{array}{c}5 \\
(3.57) \\
\end{array}$ & $\begin{array}{c}5 \\
(3.57) \\
\end{array}$ & $\begin{array}{c}140 \\
(100)\end{array}$ & 4.35 \\
\hline $\begin{array}{l}\text { To ensure administration that is } \\
\text { continuous and rule governed. }\end{array}$ & $\begin{array}{c}64 \\
(45.71) \\
\end{array}$ & $\begin{array}{c}54 \\
(38.57) \\
\end{array}$ & $\begin{array}{c}12 \\
(8.57)\end{array}$ & $\begin{array}{c}9 \\
(6.43) \\
\end{array}$ & $\begin{array}{c}1 \\
(0.71) \\
\end{array}$ & $\begin{array}{c}140 \\
(100)\end{array}$ & 4.22 \\
\hline $\begin{array}{l}\text { To accelerate improvements in service } \\
\text { delivery by harnessing ICT to modernize } \\
\text { the civil service and improve internal } \\
\text { efficiency of MDAs and integrate MDA } \\
\text { applications and on the whole to achieve } \\
\text { e-government. }\end{array}$ & $\begin{array}{c}77 \\
(55.00) \\
\end{array}$ & $\begin{array}{c}52 \\
(37.14) \\
\end{array}$ & $\begin{array}{c}7 \\
(5.00) \\
\end{array}$ & $\begin{array}{c}4 \\
(2.86) \\
\end{array}$ & $\begin{array}{c}0 \\
(0)\end{array}$ & $\begin{array}{c}140 \\
(100)\end{array}$ & 4.44 \\
\hline $\begin{array}{l}\text { To institutionalize personnel } \\
\text { management system that integrates all } \\
\text { levels of staff in the Department. }\end{array}$ & $\begin{array}{c}73 \\
(52.14) \\
\end{array}$ & $\begin{array}{c}56(40.0 \\
0)\end{array}$ & $\begin{array}{c}7 \\
(5.00) \\
\end{array}$ & $\begin{array}{c}3 \\
(2.14) \\
\end{array}$ & $\begin{array}{c}1 \\
(0.71) \\
\end{array}$ & $\begin{array}{c}140 \\
(100) \\
\end{array}$ & 4.41 \\
\hline $\begin{array}{l}\text { To ensure better coordination and } \\
\text { coherence by avoiding proliferations of } \\
\text { institutions with overlap of roles and } \\
\text { functions. }\end{array}$ & $\begin{array}{c}74 \\
(52.86)\end{array}$ & $\begin{array}{c}51 \\
(36.43)\end{array}$ & $\begin{array}{c}9 \\
(6.43)\end{array}$ & $\begin{array}{c}6 \\
(4.29)\end{array}$ & $\begin{array}{c}0 \\
(0)\end{array}$ & $\begin{array}{c}140 \\
(100)\end{array}$ & 4.38 \\
\hline $\begin{array}{l}\text { To increase public trust for the } \\
\text { administration }\end{array}$ & $\begin{array}{c}81 \\
(57.86)\end{array}$ & $\begin{array}{c}45 \\
(32.14)\end{array}$ & $\begin{array}{c}7 \\
(5.00)\end{array}$ & $\begin{array}{c}6 \\
(4.29)\end{array}$ & $\begin{array}{c}1 \\
(0.71)\end{array}$ & $\begin{array}{c}140 \\
(100)\end{array}$ & 4.21 \\
\hline $\begin{array}{l}\text { To systematically close capacity gaps in } \\
\text { the civil service through effective human } \\
\text { resource planning systems and capacity } \\
\text { building (Training). }\end{array}$ & $\begin{array}{c}103 \\
(73.57)\end{array}$ & $\begin{array}{c}27 \\
(19.29)\end{array}$ & $\begin{array}{c}4 \\
(2.86)\end{array}$ & $\begin{array}{c}5 \\
(3.57)\end{array}$ & $\begin{array}{c}1 \\
(0.71)\end{array}$ & $\begin{array}{c}140 \\
(100)\end{array}$ & 4.61 \\
\hline
\end{tabular}

\section{Source: Field work, 2020}

Table 1 shows the respondents' views on the identification of goals and objectives of civil service reforms. Objective one (1) of this study sought to find out from respondents whether the civil service reforms reinforced meritocracy, due process and professionalism in the decisions of personnel administration (appointment, discipline, promotion etc) through clear policies, structures, systems, standards and procedures. A total respondent of $96(68.57 \%)$ strongly agreed to identify reinforcement of meritocracy, due process and professionalism in the decisions of personnel administration (appointment, discipline, promotion etc.) through clear policies, structures, systems standards and procedures as a goal and objective of civil service reforms, while $41(29.29 \%)$ agreed and $2(1.43 \%)$ disagreed. The remaining $1(0.71 \%)$ of respondents were undecided.

On enhancing administrative culture that guarantees discipline, performance and good ethical conduct, a total of 92 respondents $(65.71 \%)$ strongly agreed while 41 respondents $(29.9 \%)$ agreed and $2(1.43 \%)$ disagreed. On the other hand, the remaining 5 respondents $(3.57 \%)$ decided not to identify enhancement of administrative culture that guarantees discipline, performance, and good ethical conduct as a goal and objective of civil service reform. When questions were asked to identify optimal organization and staffing of the civil service as a goal and objective of civil service reform, 73 respondents $(52.14 \%)$ strongly agreed and agreed that it aligned the overall structure of government for efficiency and effectiveness while $54(38.57 \%)$ agreed and $1(0.71 \%)$ and 1 $(0.71 \%)$ disagreed and strongly disagreed. However, 11 of the respondents $(7.86 \%)$ were undecided. 
On whether the reforms improved face of service delivery by fostering new attitudes such as increased commitment to citizen consultation, courtesy and dedication, $71(50.71 \%)$ strongly agreed, while 53 respondents (37.86\%) agreed and $6(4.29 \%)$ disagreed. The remaining $10(7.14 \%)$ were undecided to identify improved face of service delivery by fostering new attitudes such as increased commitment to citizen consultation, courtesy and dedications as a goal and objective of civil service reforms. Consequently, the above views concurred with studies like that of Corkery and Land (1997), that pointed out that reforms in the public institutions are to revamp the economic system which has been faced with challenges. This has made government to adopt certain strict measures to overhaul system through ensuring merit system; emphasises on efficiency and effectiveness (World Bank, 2004). Furthermore, in the course of the field work efforts were made for the respondents to identify whether the reforms were to attract, retain and motivate optimal number of qualified technical and professional personnel through more equitable, adequate and fair remuneration. To this statement, $34(24.29 \%)$ of the respondents agreed and $99(70.71 \%)$ strongly agreed, $5(3.57 \%)$ disagreed. However, 2 of the respondents $(1.43 \%)$ were not in the position to identify whether the reforms were to attract, retain and motivate optimal number of qualified technical and professional personnel through more equitable, adequate and fair remuneration.

The majority of the respondents (98), representing 70\%, strongly agreed to identify enhanced transparency and accountability in government as a goal and objective of civil service reform while $2(1.43 \%)$ strongly disagreed that it enhanced transparency and accountability in government. $31(22.14 \%)$ agreed and $5(3.57 \%)$ disagreed. On the other hand, $4(2.86 \%)$ of the employees could not identify whether enhanced transparency and accountability in government was a goal and objective of civil service reform.

On the need to identify whether to improve efficiency and cost effectiveness in public institutions was a goal and objective of civil service reform, 72 respondents $(51.43 \%)$ strongly agreed and $56(40 \%)$ agreed. However, $4(2.86 \%)$ of the employees disagreed and $2(1.43 \%)$ strongly disagreed. On the other hand, $6(4.29 \%)$ could not identify whether the reforms improved efficiency and cost effectiveness in public institutions.

The views shared by the respondents to identify whether to improve the image of the public service was a goal and objective of civil service reform, 53 of the employees (37.86\%) strongly agreed and $47(33.57 \%)$ agreed, 8 (5.71\%) disagreed and $6(4.29 \%)$ strongly disagreed and $26(18.57 \%)$ were undecided. On identifying whether the reforms were to institutionalize a system that engenders separation between politics and administration, $81(57.86 \%)$ strongly agreed, $42(30.00 \%)$ agreed, $5(3.57 \%)$ disagreed and $5(3.57 \%)$ strongly disagreed and $7(5.00 \%)$ were undecided. A total of 64 respondents $(45.71 \%)$ strongly agreed that one of the goals of reforms is to ensure that administration is continuous and rule governed while $54(38.57 \%)$ agreed, 9 $(6.43 \%)$ disagreed and $1(0.71 \%)$ strongly disagreed. However, $12(8.57 \%)$ of the respondents were undecided.

To accelerate improvements in service delivery by harnessing ICT to modernize the civil service and improve internal efficiency of MDAs and integrate MDA applications and on the whole to achieve egovernment, 77 respondents $(55.00 \%)$ strongly agreed to the statement, while $52(37.14 \%)$ of the respondents agreed and $4(2.86 \%)$ disagreed. The remaining $7(5.00 \%)$ of the respondents were undecided. The information gathered on whether to institutionalize personnel management system that integrates all levels of staff in the department was a goal and objective of the reform, $73(52.14 \%)$ strongly agreed to the statement, while 56 $(40.00 \%)$ agreed, $3(2.14 \%)$ disagreed and $1(0.71 \%)$ strongly disagreed. However, 7 of the employees $(5.00 \%)$ were neutral meaning they could not decide whether to institutionalize personnel management system that integrates all levels of staff in the department was a goal and objective of the reform.

On eliciting a response on whether to ensure better coordination and coherence by avoiding proliferations of institutions with overlap of roles and functions was a goal and objective of the reforms, revealed that 74 respondents (52.86\%) strongly agreed and 51 (36.43\%) agreed. On the other hand, 6 (4.29\%) disagreed while 9 $(6.43 \%)$ were undecided. Again, as to whether increasing public trust for the administration was a goal and objective of the reform, $81(57.86 \%)$ of the respondents strongly agreed and $45(32.14 \%)$ agreed. On the other hand, $6(4.29 \%)$ disagreed and $1(0.71 \%)$ strongly disagreed. A total of $7(5.00 \%)$ of the respondents did not respond to the statement that to increase public trust for the administration was a goal and objective of the reform. Findings also revealed that $103(73.57 \%)$ of the workers strongly agreed and $27(19.29 \%)$ agreed. On the other hand, $5(3.57 \%)$ disagreed and $1(0.71 \%)$ strongly disagreed. The remaining $4(2.86 \%)$ of the respondents could not in any way decide as to whether to systematically close capacity gaps in the civil service through effective human resource planning systems and capacity building was a goal and objective of the reforms. Furthermore, the grand mean was 4.49. This is an indication that responses tend towards the "agreed" option to all the attributes of goals and objectives of civil service reforms. However, out of the fifteen attributes enlisted, ten attributes had mean score that is lower than the grand mean, while five attributes had mean score that is higher than the grand mean. Deductively, goals and objectives of civil service reforms from the perspective of respondents can be said to be positive. This has been further represented in a chat in figure A below depicting certain indicators as accentuated by various respondents. 
Figure A

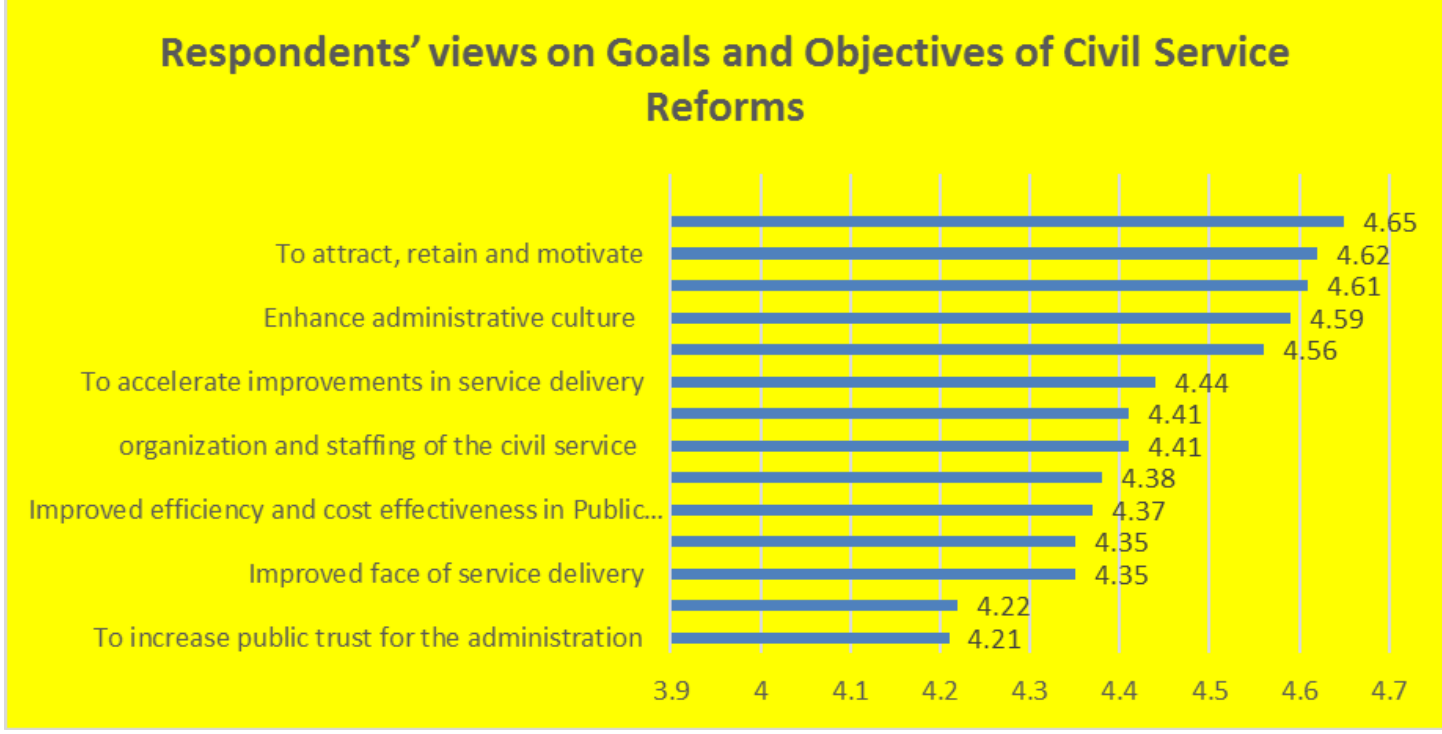

Source: Author's Field Work 2020

Figure B

\section{The constraints that hamper effectiveness of the civil service reforms in The Gambia.}

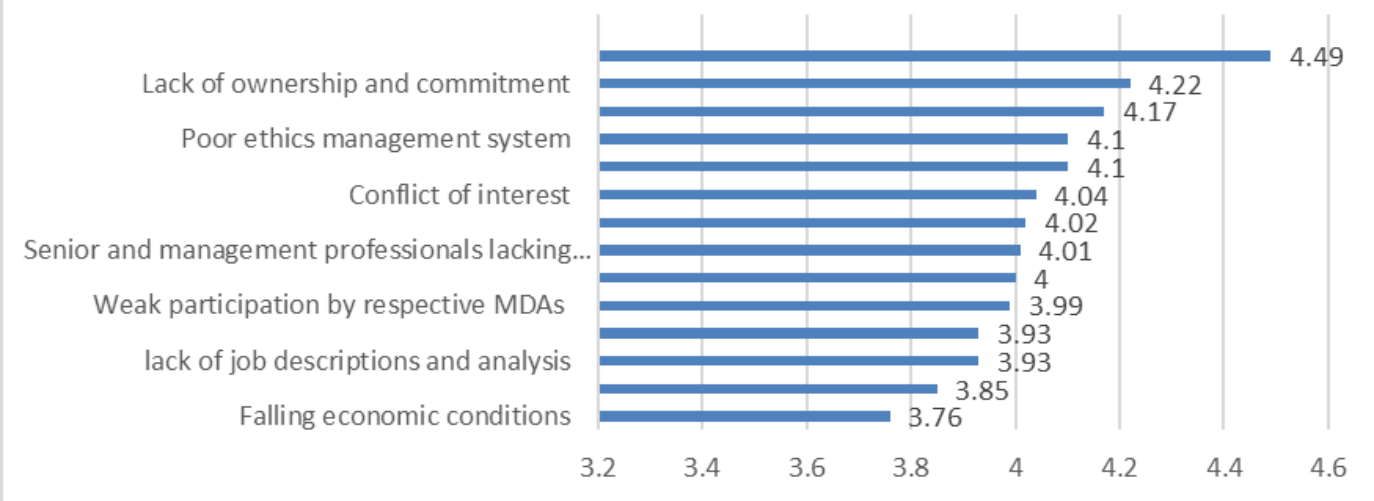

Source: Author's Field Work 2020

Interview Guide

The findings of this study also revealed that promotions are not based on any form of performance appraisal. One of the interviewees stated:

The recommendations of the past civil service reforms for the implementation of a robust performance appraisal system have not been heeded. Promotions are not based on performance but on whom you know.

Another interviewee concluded:

I joined the civil service barely ten years ago and am a Deputy Permanent Secretary while a colleague who is nine years in the service has been promoted to Permanent Secretary. I counted myself lucky compared to other permanent Secretaries who have been in the system for twenty years.

Another interviewee said: 
A robust appraisal system was introduced in this Ministry but had ceased to be operational following the redeployment of the officer-in-charge to another region. Plans are afoot to revive the system.

The findings also revealed that lack of evaluation of recruitment and selection processes, inadequate professional independence and system dominated by the political class, and promotions not based on performance appraisal hampered the reforms. To support this view, one of the interviewee's explained:

Ministries initiate the recruitment process by sending notifications to the PMO and the Public Service Commission. Thereafter, the PMO will advertise the vacant positions on behalf of the Public Service Commission. The PMO which is entrusted with the responsibility of managing the human resources of the civil service is technologically challenged to detect gaps in other ministries and thus unable to evaluate the needs of each Ministry at any given time.

\section{Discussion of Findings}

The first objective of this study was to identify the goals and objectives of civil service reforms within the scope of the study with the view to addressing pertinent issues with the entire system. The Goals and Objectives of Civil Service Reforms is to implement the New Public Management that intensifies productivity within a system. There are copious evidence from developed and developing countries on the general goal and objectives of reforms which have identified merit system; enforcement of professionalism; adherence to ethical conduct; digitisation of the system; attractive motivation package; training and retraining of staff...these are core elements of reforms as accentuated in most recent studies (Mongkol, 2011; Pollitt and Bouckaert, 2000 cited in Pătrașcu, 2018; Nelipa et al., 2020). Consequently, in the course of the field work in this study, most respondents subscribed to the need for institutions in the Gambia to intensify and adhere to the merit system and goals of modern civil service reforms processes.

The report from the field revealed that a total respondent of $96(68.57 \%)$ strongly agreed to identify reinforcement of meritocracy, due process and professionalism in the decisions of personnel administration (appointment, discipline, promotion... and so on) through clear policies, structures, systems standards and procedures as a goal and objective of civil service reforms, while 41 (29.29\%) agreed and 2(1.43\%) disagreed. The remaining $1(0.71 \%)$ of respondents were undecided. The other variables used in the course of this study also attracted large per centages in favour of optimal organization and staffing of the civil service that align the overall structure of government for efficiency and effectiveness; enhance transparency and accountability in government...as stated in table 4.1.1a. These variables have been identified in extant literature premised on merit system; optimisation; professionalism... as way of reforms. They have also noted that in most developing countries challenges of weak institutions within the political system have made reforms process a herculean task which respondents noted in the course of the field work (Filardo, 2020; Bender et al. 2020).

These data as noted by various respondents in this study correspond to other developing countries reform process in developing economies. In recent times, developing countries have change the old narrative of the developmental path of most these countries. The cases of Nepal's Public Service Commission; public institutions developing states like the Malaysia's delivery unit, Pemandu (Pătrașcu, 2018). These have given a testimony and contributed to a robust, fruitful and diverse repertoire of reform approaches than generally realized. According to Pătrașcu (2018) noted that this has created an atmosphere to help reformers to expand the "reform space" available within the political economy. He concluded and identified the place of Donors as part of the system to facilitate reforms in the spirit of the Busan Partnership rather than impose their preferred models. Willy Pătrașcu pointed out that creative problem solving mechanism by national players enabled by external bodies (donors) with the view of building on profitable cases of reform success and been cognisance of data in developing and developed country reform approaches.

This was corroborated by earlier studies conducted by UNDESA on Size and Cost, in 1992; and evidence in Etuk, (1992); Cohen, (1993); Catlett and Schuftan, (1994), Picard, (1999); Ayee, (2001) in Ghana, Nigeria, Kenya and South Africa which revealed certain weaknesses bedeviling civil services. Below are the various findings:

"In Ghana there are the challenges on Poor morale; Poor pay, benefits incentives; inadequate supervision and accountability; High levels of absenteeism; Ineffective promotion and career development policies and procedures; Poor performance appraisal practices; poorly designed jobs; Poor human resource management and hostile environment."

"In Kenya Poor management of financial resources; Lack of accountability framework and enforcement; Laxity at work; Lack of good records, data and management; Lack of clear performance targets and standards; Job dissatisfaction; Poor pay, bribery and favoritism; and Poor management of budgetary flows."

"In Nigeria, the following issues have been recognized as a challenge: Highly regimented and militarized; Slow in responding to technological changes and modern organizational methods; Poor work arrangement highly 
hierarchical operational structure, un streamlined organizational structure; Sycophantic because civil servants feel that it is safer to conform than initiate; Lacking in financial and material resources; Corrupt in virtually all affair because of insecurity of tenure, poor remuneration and glorification of materialism by society; Grossly indiscipline and negative poor ethics; Declining efficiency, effectiveness and productivity; Disregard and disrespect by some members of the political class, the business community and other public servants.

\section{Concluding Remarks}

This study explored civil service reforms and personnel administrative system and practices in Gambian civil service institutions. The study achieved three objectives. First, it identified the goals and objectives of civil service reforms in The Gambia. Second, it evaluated the effects of civil service reforms on personnel administrative systems and practices on the civil service institutions of The Gambia. Third, the study identified and analysed the constraints that hampered the effectiveness of the reforms in The Gambia civil service.

Findings revealed that the four Ministries/Departments/Agencies strongly agreed to identify the 15 variables as goals and objectives of civil service reforms in The Gambia. These goals and objectives include reinforcement of meritocracy, enhance administrative culture, close capacity gaps, improve service delivery, strengthening institutional effectiveness, optimal organization and staffing of the civil service, improved efficiency and cost effectiveness, separation between administration and politics, modernize the civil service and improve internal efficiency, and to institutionalize performance management.

Pertaining to the challenges that hamper effectiveness of the reforms in the Gambia Civil Service institutions, the findings revealed: lack of competent administrative and management professional resulting to poor institutional capacity, continuous poor motivation of workers because of poor working and employment conditions of service, lack of communication and non-involvement of the public servants at drafting stage, proliferation of public service institutions with overlap of roles and functions, senior and management professionals lacking political neutrality, poor ethics management system, conflict of interest between reform target and the interest of the public servants, lack of ownership and commitment to civil service reform agenda by both the top administrators and the political class and non-availability of monitoring and evaluation system as regards to recruitment, discipline and promotion exercises in the civil service, did hamper it.

The evidence presented in this study suggested that civil service reforms and personnel administrative systems and practices in the Gambian civil service institutions were not enhanced or improved as expected resulting in a plethora of consequences in terms of weak recruitment and appointment procedures, subjective promotion system, proliferation of institutions with overlapping functions, lack of champion to drive reform process, inadequate capacity, poor service delivery and poor working conditions.

\section{References}

Adamolekun, L. (1986) Politics and Administration in Nigeria. (London: Hutchinson and Ibadan: Spectrum Books).

Ayee, J.R.A. (2001). Civil service reform in Ghana: A case study of contemporary reform problems in Africa. African Journal of Political Science, 6(1), 1-14.

Bender, K., Rohregger, B., Kinuthia, B., Ikua, G., Schüring, E., Adamba, C., Alatinga, K. A., \& Pouw, N. (2020). Different pathways of social protection reforms: An analysis of long-term institutional change in Kenya. World Development, 137. https://doi-org.nwulib.nwu.ac.za/10.1016/j.worlddev.2020.105210

Catlett, M. and Schuftan, C. (1994) Lessons from Institution Building in Kenya, Public Administration and Development, 14: 153-168.

Ceesay, E.J (2006). The Military and Democratization In The Gambia: 1994-2003 (Victoria: Trafford Publishing).

Cohen, J.M. (1993) Importance of Public Service Reform: The Case of Kenya, Journal of Modern African Studies, 31(3): 449-476.

Etuk, E. (1992) The Nigerian Public Service: In Search of Creative Excellence (Ibadan: Spectrum Books Ltd).

Farazmand, A. (1999). Administrative reform in global perspectives: A symposium. International Journal of Public Administration, 22(6), 805-813

Filardo, A. (2020). Monetary Policy Operating Frameworks: Are Reforms Heading in the Right Direction? Cato Journal, 40(2), 385-408

Mano, W., \& Milton, V. C. (2020). Civil society coalitions as pathways to PSB reform in Southern Africa. Interactions: Studies in Communication \& Culture, 11(2), 135-158. https://doiorg.nwulib.nwu.ac.za/10.1386/iscc_00015_1

Nelipa, D., Rudenko, S., Teremko, V., \& Vnuchko, S. (2020). Improving the Quality of Civil

Service Management in Ukraine. Scientific Bulletin of National Mining University, 2, 143-147. https://doiorg.nwulib.nwu.ac.za/10.33271/nvngu/2020-2/143

Nelipa, D., Rudenko, S., Teremko, V., \& Vnuchko, S. (2020). Improving the Quality of Civil 
Service Management in Ukraine. Scientific Bulletin of National Mining University, 2, 143-147. https://doiorg.nwulib.nwu.ac.za/10.33271/nvngu/2020-2/143

Picard, Louis A. (1999) "South Africa", in Adamolekun, L. Ed. (1999) Public Administration in Africa: Main Issues and Selected Country Studies (Boulder, CO.: Westview), Chapter 18.

Sen, A., Nepal, R., \& Jamasb, T. (2018). Have Model, Will Reform: Assessing the

Outcomes of Electricity Reforms in Non-OECD Asia. Energy Journal, 39(4), 181-209. https://doiorg.nwulib.nwu.ac.za/10.5547/01956574.39.4.asen

Tarro, M.L. (2020). Civil Service Reforms and Personnel Administration Systems and Practices in the

Civil Service Institutions of The Gambia. Unpublished PhD Thesis in the Department of Public Administration, School of Business and Public Administration, University of The Gambia.

The World Bank (2020). The Gambia to Advance Reforms in the Electricity and Telecom Sectors https:/www.worldbank.org/en/news/press-release/2020/05/14/the-gambia-to-advance-reforms-in-theelectricity-and-telecom-sectors. Accessed December, 2020.

UNDESA (1992) Size and Cost of the Civil Service: Reform Programmes in Africa (New York: Department of Economic and Social Development).

Ukwandu Damian C., \& Ijere Emmanuel S. (2020). Public sector reforms and national development: a situational analysis of post-independent Nigeria. Africa's Public Service Delivery and Performance Review, 8(1), 1-7. https://doi-org.nwulib.nwu.ac.za/10.4102/apsdpr.v8i1.354 